\title{
VII Pielgrzymkowy Rajd Świętokrzyski - rozwijanie zainteresowań przyrodniczych
}

\author{
Szukajmy kontaktu z przyroda, a znajdziemy \\ energię i tężyznę naszemu ciału. \\ Przyroda nas żywi, uczy, leczy, koi, kocha i raduje. \\ A. Cz. Klimuszko
}

Kształtowanie prawidłowej świadomości prośrodowiskowej uczniów jest od pewnego czasu jednym z głównych zadań edukacyjnych szkoły. Istnieją różne sposoby wprowadzania tych treści do procesu nauczania - uczenia się. Jedne z nich zakładają mówienie o zagadnieniach środowiskowych oddzielnie na poszczególnych przedmiotach, inne zaś proponują włączenie ich do treści integrując wiedzę. Obecnie na oczach każdego nauczyciela kształtuje się społeczeństwo konsumpcyjne, w którym szczęście pojmowane jest jako posiadanie rzeczy, dóbr materialnych, a przyroda służy jedynie zaspokajaniu potrzeb.

Wobec tego należy zadać pytanie - Jak zatem powinno wyglądać ksztaltowanie postawy proekologicznej uczniów? - odpowiedź znajdziemy podczas stosowania różnorodnych form i metod nauczania tak wdrażanych w proces, aby obejmowały również aspekty wychowawcze.

Jednakże bez względu na to, jak realizowana jest edukacja środowiskowa w szkole, najważniejszym celem wszystkich oddziaływań nauczyciela wobec ucznia jest kształtowanie pozytywnej postawy - otwartej, twórczej, innowacyjnej, którą można przełożyć na konkretne czyny. Systematyczne wprowadzanie dzieci w świat przyrody, ukazywanie zależności w niej panujących, problemów z jakimi się boryka szczególnie $w$ dobie współczesnych zagrożeń jest nie tylko możliwe, ale wręcz konieczne.

To stopniowe wdrażanie $\mathrm{w}$ świat przyrody powinno rozpocząć się stosunkowo wcześnie, ponieważ to najmłodsi wykazują dużą wrażliwość na otoczenie przyrodnicze, są podatni na oddziaływania wychowawcze i z niezwykłą łatwością wchodzą w bezpośredni kontakt ze środowiskiem przyrodniczym. Dlatego tak istotną rolę w procesie nauczania - uczenia się odgrywa prowadzenie zajęć w te- 
renie, które dają uczniom możliwość pełniejszego poznania danego zagadnienia i bezpośredniego doświadczenia. Nic bardziej nie zbliża dzieci do przyrody jak bezpośredni z nią kontakt. Zasadnym jest zawsze, jeśli tylko pozwalają na to możliwości wychodzić poza szkołę.

W trakcie prowadzenia zajęć terenowych warto pokierować obserwacją tak, aby uczniowie wynieśli z nich jak najwięcej wiedzy i pomysłów możliwych do samodzielnej realizacji. $\mathrm{Za} \mathrm{każdym} \mathrm{razem} \mathrm{proponując} \mathrm{prowadzenie} \mathrm{dokumentacji}$ z obserwacji. Mogą to być dzienniki obserwacyjne, karty obserwacyjne gromadzone w specjalnie do tego celu założonych segregatorach, notatniki przyrodnicze, zielniki, arkusze obserwacyjne, zdjęcia, filmy itp. Pozyskane w ten sposób materiały są niezwykle cenne dla ucznia, gdyż samodzielnie je sporządził jak i dla nauczyciela, ponieważ stanowią wspaniałą pomoc dydaktyczną. Wszelkie formy takiej dokumentacji to dodatkowa praca dla dziecka, którą jednak wykonuje chętnie, zwłaszcza, że w niektóre prace zaangażowane są również najbliższe osoby - rodzice czy rodzeństwo. Stwarza to możliwość wspólnej pracy i zabawy w domu. Dzięki licznym wyjściom w teren uczniowie mają również okazję poznania najpiękniejszych rejonów i jego historii.

W czasie tych zajęć zarówno uczniowie słabsi, jak i ci szczególnie uzdolnieni mogą wykazać się własną pomysłowością, każdy z nich ma coś do powiedzenia i wszystkie uwagi są cenne. Często właśnie podczas takich wyjść zauważyć można u uczniów cechy, które trudno dostrzec w czasie tradycyjnych zajęć.

Prowadząc edukację środowiskową należy mieć świadomość faktu, że własny entuzjazm jest zaraźliwy i że to właśnie on jest najlepszą predyspozycją do roli jaką nauczyciel chce pełnić. Dzieci w naturalny sposób dążą do wiedzy, a prowadzącemu jeśli udaje się utrzymać nastrój entuzjazmu i radości, to zajęcia są interesujące, bogate i zróżnicowane.

Należy stwierdzić, że wiele jest jeszcze do zrobienia w tej materii i bez względu na posiadany obecnie poziom wiedzy, warto ciągle doskonalić się zawodowo i nigdy nie wychodzić z założenia, że wszystko zostało już zrobione. Mając na uwadze znane powiedzenie Lestera Browna: „Nie odziedziczyliśmy Ziemi po naszych przodkach, ale pożyczyliśmy ją od naszych dzieci." można stwierdzić, że właśnie edukowanie najmłodszych od pierwszych lat nauki szkolnej przyniesie oczekiwane owoce w postaci prawidłowych postaw - ludzi świadomych zagrożeń, aktywnie działających na rzecz życia na czystej Ziemi, ludzi, którzy swoją postawą udowodnią jak ważne jest rozumienie roli i znaczenia przyrody w życiu każdego człowieka.

Naturalna dążność do kontaktu dziecka z przyrodą polega na odczuwaniu przez nie emocjonalnej $z$ nią więzi, na pragnieniu przebywania $w$ środowisku. Kontakt z przyrodą wywołuje silne uczucie, gotowość do poznawania jej, ochrony i uczestnictwa w jej życiu. Dobrze zorganizowane obserwacje zjawisk przyrodniczych stanowią właściwą bazę dla rozwoju pamięci, myślenia, zdolności, a od- 
czucia estetyczne związane z przeżywaniem piękna przyrody są niezwykle motywujące do podejmowania działalności praktycznej związanej bezpośrednio z jej ochroną. Kształtowanie szacunku wobec przyrody obejmuje zrozumienie faktu, że przyroda jest dla człowieka użyteczna i dlatego należy ją szanować. Uczeń dostrzega i rozumie, że wszystko co jest niezbędne do życia czerpie z niej.

Atuty, jakimi dysponuje polska edukacja są godne wyeksponowania ze względu na ich wyjątkowość i nieporównywalność z podobnymi formami edukacji w krajach Unii Europejskiej. Jedną nich są zajęcia terenowe, które jako forma organizacji procesu dydaktycznego dają ogromne możliwości kształtowania podstaw wiedzy środowiskowej niezbędnej każdemu człowiekowi. Poza aspektem poznawczym, mają ogromne walory wychowawcze. Przede wszystkim umożliwiają kształtowanie właściwych sposobów zachowań poza szkołą, aktywizują działania grupowe, integrują klasę, sprzyjają ujawnianiu się aktywności poszczególnych uczniów. (Grzegorek, 1999)

Dlatego kształcenie formalne odbywające się w szkołach różnego szczebla jest ściśle związane z nauczaniem nieformalnym przebiegającym poza placówkami szkolno -wychowawczymi. Dokonuje się ono poprzez przekazywanie informacji za pomocą mediów, lekturę uzupełniającą, instytucje, które oprócz innych zadań wpisanych w swój statut zajmują się edukacją. Formy kształcenia formalnego i nieformalnego uzupełniają się wzajemnie, dostarczając uczniom szeregu interesujących wiadomości, a jednocześnie wpływają na doskonalenie umiejętności i ksztaltowanie szeregu pozytywnych postaw. Wyżej wymienione formy nauczania - uczenia się powinny być wzbogacane ofertą działających na terenie niektórych miast instytucji zajmujących się edukacją ekologiczną dzieci i młodzieży. Inicjatywy podjęte w celu ochrony przyrody na każdym szczeblu nauczania mają sens tylko wtedy, gdy poparte są aktywnymi formami edukacji. Przynosić to będzie wymierne efekty w postaci wiedzy, nawyków, przyjaznych postaw wobec ludzi i przyrody, ale muszą być poparte rzetelną wiedzą merytoryczną, którą nabywa się w sposób ciągły, konsekwentnie i powoli.

Obecnie szkoła nie jest i nie może być jedynym źródłem wiedzy środowiskowej, nie może również skutecznie kształtować odpowiednich postaw koniecznych do wychowania w kulturze, nie współdziałając w procesie edukacyjnym $\mathrm{z}$ innymi instytucjami i organizacjami zajmującymi się tą problematyką.

Edukacja środowiskowa prowadzona przez pracowników instytucji wspierających szkołę w ramach nieformalnej edukacji, nie ogranicza się wyłącznie do funkcji informacyjnej. Zdobyte w jej toku wiadomości i nabyte umiejętności znajdują zastosowanie bezpośrednio w praktycznym działaniu, w życiu codziennym, w planowanych, podejmowanych i realizowanych inwestycjach proekologicznych. 
Planowanie zajęć terenowych przy pomocy „koła pytań”

Planow'anie zajęc terenowych prà pomocy „kola pytań"

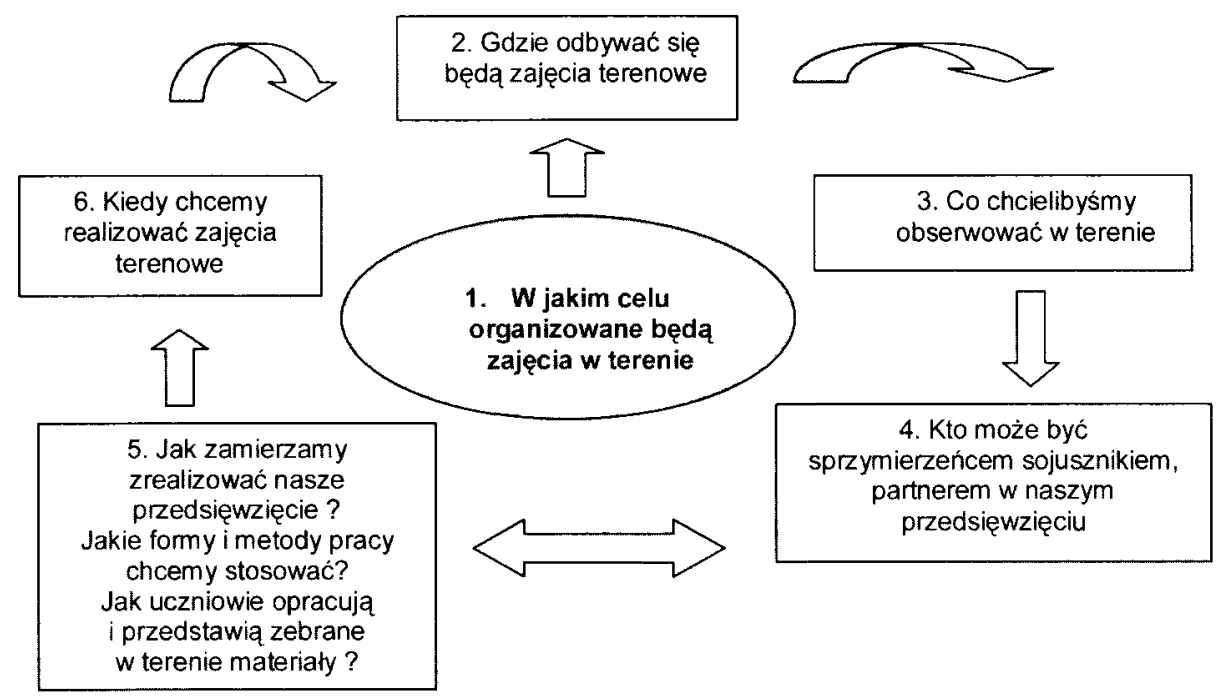

Odział Świętokrzyski PTTK w Kielcach, Wydział Duszpasterstwa Ogólnego Diecezji Kieleckiej, Klasztor Ojców Misjonarzy Oblatów na Świętym Krzyżu oraz Federacja Przewodników Świętokrzyskiego PTTK w Kielcach po raz siódmy zorganizowali Pielgrzymkowy Rajd Świętokrzyski, którego celem było:

- uczczenie relikwii Krzyża Świętego,

- poznanie historii klasztoru na Łysicy,

- podziwianie piękna Gór Świętokrzyskich,

- kształtowanie postaw i zachowań ekologicznych,

- poznanie patrona tras.

Co roku rajd odbywa się w ostatnią sobotę września, niezależnie od pogody. Patronatem objęli go Ordynariusze trzech Diecezji: kieleckiej, sandomierskiej i radomskiej, a przede wszystkim Prymas Polski ks. Kardynał Józef Glemp, Marszałek woj, świętokrzyskiego, Wojewoda świętokrzyski i Prezydent Kielc.

Organizatorzy przygotowali wiele tras rajdowych, w większości pieszych, ale też autokarową, pieszą i rowerową. Każda z nich miała swojego patrona, a każda grupa zawodowego przewodnika z PTTK-u.

Poszczególne grupy wyruszyły z różnych miejsc w Górach Świętokrzyskich, aby po kilku godzinach wędrówki spotkać się na Świętym Krzyżu i uczestniczyć we Mszy Św. Koncelebrowanej pod przewodnictwem Prymasa Polski w intencjach: za pomyślność Ojczyzny, za Papieża-Polaka (Honorowego Przewodnika Swiętokrzyskiego), za uczestników rajdu i ich rodzin. 
- Trasa nr 1 - „Puszczańska” (Trasa cały czas przebiega przez puszczę Jodłową).

- Trasa nr 2 - „Krajem Puszczy” - Podobnie jak Krajno, bierze nazwę od brzegu - a'skraja puszczy [nazwa powstała analogicznie od nazwy obszaru u brzegu Rzeczpospolitej - Ukrainy].

- Trasa nr 3 - „Rudna” (W Płuckach płukano rudy metali wydobywane z orudowanych wodami termalnymi lejów krasowych).

- Trasa nr 4 - „Jeleniowska” (W dawnych czasach bywały i są tu jelenie, stąd nazwa miejscowości i pasma górskiego oraz trasy).

- Trasa nr 5 - „Słowiańska” - Trasa prowadzi od Makoszyna, obok którego czczono żeńskie bóstwo Mokoszę [wały kultowe w miejscu zwanym Zamczysko] na Święty Krzyż, gdzie przed chrystianizacją był jeden z największych ośrodków kultu pogańskiego [wały oddzielające sakrum od profanum są widoczne $\mathrm{w}$ wielu miejscach - na gołoborzach, przy drodze królewskiej do Nowej Słupi].

- Trasa 6 - „Żeromiowa” (Tuż obok trasy są żeremia bobrowe. Wprawdzie bobry tak się rozmnożyły, że powodują straty gospodarcze, jest ich sporo, jednak są mało znane. Występują również w literaturze i są związane z dawną polską medycyną oraz kuchnią. [ze względu na pokryty łuską ogon uważano je za postne, pokrewne rybom jedzenie]).

- Trasa nr 7 - „Zbójecka” (Po zawiśnięciu zbója Kaka na szubienicy na krakowskim rynku część jego skarbów odnalazł niejaki Grzegorczyk. Połową wspomógł budowę bielińskiego kościoła, drugą połową skarbów polepszył swój los. Jego legendę spisał Józef Ozga Michalski z Bielin, wspomniał to podanie w swych publikacjach regionalnych Jerzy Fijałkowski. Gdzieś tu mieszkał również Zbój Skalny - Jaśko Ozga opisany przez Stanisława Orła w powieści „Zbój Świętokrzyski”. Zresztą i dziś można natknąć się na zbójów, w końcu to kraina legend).

- Trasa nr 8 - „Truskawkowe Pola” (Słyszeliście te piosenkę The Beatles? Napisali ją wędrując tą trasą. Rozejrzyjcie się).

- Trasa nr 9 - „Modrzewiowa” (Odmiana modrzewia odkryta i opisana przez Raciborskiego nosi miano Modrzewia Polskiego (Larix Poloniae Raciboriensis). Później okazało się, że rezerwat na Chełmowej Górze utworzony dla jego ochrony to północna granica występowania a matecznik tej odmiany jest w Rumunii).

- Trasa nr 10 - „Dworska” (Dwory w Chybicach [zamieszkały jeszcze 15 lat temu], zamieszkały dwór w Starej Słupi, podworski spichlerz w Pokrzywnicy. Z Chełmowej Góry widać dwory lub miejsca po nich w Skałach, Garbaczu, Grzegorzewiczach, Mirogonowicach, Jeleniowie, Skoszynie, Nagorzycach, nadal zamieszkałe we Wronowie, Rzepinie, Sadkowicach)

- Trasa nr 11 - „Trzy Krzyże” (Przy wejściu w puszczę po południowej stronie, stoi pomnik poświęcony Polakom pomordowanym przez funkcjonariuszy stalinowskiego totalitaryzmu. Ma formę trzech krzyży upamiętniających trzy naj- 
większe miejsca kaźni. Nazwa trasy nawiązuje do wyróżniającego się elementu krajobrazu i jego form upamiętnienia zamordowanych rodaków).

- Trasa nr 12 - „Benedyktyńska” (Wszystkie miejscowości na tej trasie są związane z długoletnią działalnością gospodarczą. Benedyktynów - z hutā̄i szkła produkującymi opakowania szklane dla apteki i do szklenia okien)

- Trasa nr 13 - „Partyzancka” (Miejsce bojów przy wykorzystaniu taktyki partyzanckiej w powstaniu styczniowym [Langiewicz i inni] w czasie II wojny światowej [Ponury, Barabasz i inni]

Celem rajdu było oddanie czci reliktom Krzyża Świętego, a także poznanie walorów przyrodniczych, historycznych i kulturowych Gór Świętokrzyskich i Świętokrzyskiego Parku Narodowego. Msza św. była sprawowana na stopniach Muzeum. Wszyscy zostali życzliwie przyjęci przez Kustoszy klasztoru na Świętym Krzyżu Ojców Misjonarzy Oblatów. Rajd daje możliwość dobrej szkoły wiary, życzliwości i poszanowania.

Słowa uznania należą się Przewodnikom świętokrzyskim, którzy jako wolontariusze podejmują się prowadzenia grup rajdowo - pielgrzymkowych.

Trasy rajdu prowadziły po najpiękniejszych zakątkach Gór Świętokrzyskich a jego zakończenie i spotkanie wszystkich turystów - pielgrzymów odbyło się w klasztorze na Św. Krzyżu. W tej organizowanej od kilku lat turystyczno - religijnej imprezie, najliczniejszą grupę stanowią uczniowie i do nich w dużym stopniu adresowana jest oferta uczestnictwa w rajdzie.

Doświadczenia tegoroczne jak również lat ubiegłych potwierdzają ogromne zainteresowanie, zadowolenie „z przebytych kilometrów i obcowania z przyrodą" wśród dzieci i młodzieży szkolnej dla których jest to możliwość zdobywania wiedzy w bardzo przyjemny i innowacyjny sposób. Trzynaście tras rajdowych prowadziła grupa doświadczonych przewodników świętokrzyskich, którzy przekazali uczestnikom wędrówki szeroką i wszechstronną wiedze historyczną, przyrodniczą i geograficzną, realizując przy tym jeden z głównych celów rajdu tj. kształtowanie postaw oraz zachowań w duchu wzajemnej miłości międzyludzkiej i poszanowania otaczającego świata.

Wiedza o środowisku, którą uczniowie nabywają przed wejściem w dorosłe życie jest niezwykle istotna. Ważny jest podstawowy zasób wiadomości i praktycznych umiejętności, a także nawyków i postaw, które pozwolą na właściwe funkcjonowanie młodych ludzi w szeroko pojętym środowisku. Koniecznym elementem współczesnej edukacji jest odpowiednie przygotowanie uczniów do podejmowania racjonalnych działań służących ochronie przyrody, poprawie stanu środowiska, dostrzegania zagrożeń cywilizacyjnych oraz rozwiązywania problemów stwarzanych w środowisku przez człowieka.

Edukacja środowiskowa stanowi jedno z globalnych wyzwań ludzkości. Cały świat odczuwa skutki cywilizacji i nadmiernej ingerencji człowieka w podstawowe procesy ekologiczne. 
Dlatego obowiązkiem władz szkolnych jest umożliwienie wszystkim kształcącym się, poznanie podstawowych praw przyrody i zasad prawidłowego funkcjonowania w środowisku.

Ochrona środowiska to moralny obowiazek czlowieka - kontynuujcie Wasze dzieto uwrażliwiania na ochronę środowiska. Propagujcie wlaściwa kulturę wartości naszego świata natury. Popierajcie szacunek dla stworzenia"

Jan Paweł II

\section{Bibliografia}

Cichy D. 2002: Zmiany w edukacji biologicznej i środowiskowej w szkolach ponadgimnazjalnych. Edukacja Biologiczna i Środowiskowa.1.

Grzegorek J.1999: Gimnazjum - program nauczania. Biologia XXI, WSiP, Warszawa

Regulamin - VII Pielgrzymkowy Rajd Świętokrzyski "Trwajcie mocni w wierze”

http://www.kielce.opoka.org.pl

http://www.spbolmin.simset.net/rajd.htm

http://www.kuratorium.kielce.pl/tresc/wypoczynek/turystyka/12 